Didaché: Journal of Christian Education

Vol. 2, No. 2 (2021): 133-144

e-ISSN: 2722-8584

Published by: Sekolah Tinggi Teologi Simpson Ungaran

DOI: $10.46445 /$ djce.v2i2.441

\title{
Peran dan Kendala Orang Tua dalam Pendampingan Pembelajaran Siswa Pendidikan Agama Kristen di Masa Pandemi Covid-19
}

\author{
Desserly Krismawaty Wesly, Edi Sujoko, Riniwati \\ Sekolah Tinggi Teologi Simpson Ungaran \\ Email: desserlykrismawes@gmail.com
}

\begin{abstract}
The role of parents is a determining element of student success during the Covid-19 pandemic. Achieving success in children's education cannot be separated from the vital role of parents, who are the primary source in children's education. The research question is: What is parents' role in Christian Religious Learning during the Covid-19 pandemic at SDN 02 Kalirejo in the 2019/2020 academic year? The method used in this research is descriptive qualitative. The results of this study indicate that parents act as teachers, motivators, facilitators, and mentors. Then it was also found that not all parents of students have played their role in the distance learning process during the Covid-19 pandemic. This is due to several factors, including an incomplete understanding of the role of parents in the distance learning process; minimal socialization about the role of parents in distance learning either from schools or educators; distance learning is new for parents; working parents cause the time allocation to be minimal.
\end{abstract}

Keywords: Role of Parents, Distance Learning, Covid-19

\begin{abstract}
Abstrak
Peran orang tua menjadi unsur penentu keberhasilan siswa di masa pandemi Covid-19. Pencapaian suatu keberhasilan dalam pendidikan anak tidak terlepas dari peran penting orang tua yang menjadi sumber utama di dalam pendidikan anak. Pertanyaan penelitian ini adalah bagaimana peran orang tua pada Pembelajaran Agama Kristen di masa pandemi Covid-19 di SDN 02 Kalirejo tahun ajaran 2019/2020? Metode yang digunakan dalam penelitian ini adalah kualitatif deskriptif. Hasil penelitian ini menunjukkan bahwa orang tua berperan sebagai guru, motivator, fasilitator, dan pembimbing. Kemudian ditemukan pula bahwa belum semua orang tua siswa menjalankan perannya dalam proses pembelajaran jarak jauh di masa pandemi Covid19. Hal tersebut disebabkan beberapa faktor, diantaranya: pemahaman yang belum utuh tentang peran orang tua dalam proses pembelajaran jarak jauh; sosialisasi yang minim tentang peran orang tua dalam pembelajaran jarak jauh baik dari sekolah ataupun pendidik; pembelajaran jarak jauh merupakan hal yang baru bagi orang tua siswa; orang tua yang bekerja menyebabkan alokasi waktu menjadi minim.
\end{abstract}

Kata Kunci: Peran Orang Tua, Pembelajaran Jarak Jauh, Covid-19

D.K. Wesly, et al., Peran dan Kendala Orang Tua dalam Pendampingan Pembelajaran.... 133 


\section{Pendahuluan}

Undang-undang nomor 20 tahun 2003 tentang sistem pendidikan Nasional pasal 1 ayat 1 menyatakan bahwa pendidikan adalah usaha sadar dan terencana untuk mewujudkan suasana dan proses pembelajaran aktif dan mengembangkan potensi siswa sehingga memiliki kekuatan spiritual keagamaan, pengendalian diri, kepribadian, kecerdasan, akhlak mulia, serta keterampilan yang diperlukan dirinya, masyarakat, bangsa dan negara (Undang-Undang Republik Indonesia Nomor 20 Tahun 2003 Tentang Sistem Pendidikan Nasional, n.d.). Hal tersebut artinya pendidikan merupakan hal yang sangat penting bagi siswa untuk mengembangkan aspek akademis dan non-akademis. Dalam upaya peningkatan aspek akademis maupun non-akedemis tersebut dibutuhkan peran serta orang tua secara sadar dan berkelanjutan.

Kolaborasi antara pendidik dan orang tua merupakan sebuah keniscayaan untuk mewujudkan tujuan pendidikan seperti yang telah diamanatkan dalam tujuan pendidikan nasional Indonesia (Handayani, 2020; Ritonga, 2020). Namun dalam implementasinya peran guru dianggap lebih penting dalam proses pendidikan formal dibandingkan dengan peran orang tua (Darmawan, Nalle, Magdalena, Marderina, \& Julita, 2021). Hal itu tercermin dari tingkat kepatuhan siswa kepada pendidik lebih tinggi dibandingkan kepatuhan siswa kepada orang tua kehidupan sehari-hari, khususnya dalam proses pembelajaran. Meski demikian kondisi tersebut mulai terjadi pergeseran di mana peran orang tua lebih meningkat dibandingkan peran guru di masa pandemi Covid-19 ini. Orang tua dituntut berperan sebagai pendidik, motivator, fasilitator dan pembimbing selama pembelajaran jarak jauh (Darmawan et al., 2021). Hal tersebut bukanlah tanggung jawab yang ringan bagi orang tua untuk menjalankan perannya untuk mendampingi pendidikan putra-putrinya di masa pandemi Covid-19 ini. Tentu saja akan membutuhkan kerja keras serta penyesuaian yang harus dilakukan (Darmawan et al., 2021; Ekayanti \& Puspawati, 2020). Hal tersebut memaksa orang tua untuk meningkatkan perannya dalam mendampingi putra atau putrinya dalam proses pembelajaran daring (Darmawan et al., 2021). Peran orang tua akan menjadi unsur penentu keberhasilan siswa di masa pandemi Covid-19 ini. Secara teologis, orang tua memiliki peran penting untuk keberhasilan anak, oleh sebab itu peran orang tua perlu dioptimalkan (Nainupu \& Emiyati, 2020). 
Implementasi pembelajaran jarak jauh memiliki tingkat kesulitan bagi pendidik, siswa dan orang tua (Handayani, 2020). Bagi siswa Sekolah Menengah Atas (SMA) atau Sekolah Menengah Kejuruan (SMK) akan relatif lebih mudah dalam mengimplementasikan pemanfaatan teknologi dan informasi dalam proses pembelajaran jarak jauh dibandingkan dengan siswa tingkat di bawahnya, sehingga hambatan pendidik dan orang tua tidak mengalami kesulitan yang berarti (Purwanto et al., 2020). Sebaliknya, bagi siswa Sekolah Dasar (SD) dan Sekolah Menengah Pertama (SMP) akan menghadapai berbagai tantangan dalam proses belajarnya. Misalnya, hambatan dalam pemanfaatan media pembelajaran, hambatan motivasi siswa, hambatan inisiatif, dan lain sebagainya. Siswa Sekolah Dasar akan lebih terdampak dari sistem pembelajaran yang saat ini diimplementasikan oleh pemerintah dan sekolah yaitu pembelajaran jarak jauh. Penelitian Pramana et al. (2021) menunjukkan adanya kendala yang perlu dipecahkan dalam pembelajaran jarak jauh. Penelitian terdahulu yang dilakukan oleh Diana et al., (2021) menunjukkan bahwa orang tua berperan untuk menyelenggarakan pendidikan anak selama masa pandemi. Demikian pula penelitian Darmawan et al. (2021) juga menunjukkan ada peran penting orang tua untuk mewujukan pembelajaran anak di rumah. Kedua penelitian tersebut menunjukkan orang tua memegang peranan penting.

Sebelum masa pandemi, proses belajar di SDN 02 Kalirejo berjalan dengan baik. Namun pada masa pandemi Covid-19 proses belajar mengajar dengan tatap muka menjadi terhalang dikarenakan adanya pandemi yang mengakibatkan proses pembelajaran di sekolah menjadi terganggu. Masa pandemi ini menjadi masalah bagi dunia pendidikan, namun tetap harus memberikan ilmu kepada siswa. Sehingga SDN 02 Kalirejo Ungaran Timur menetapkan keputusan agar siswa belajar dari rumah, dengan harapan bahwa pendidik menyediakan bahan pelajaran bagi siswa, dan proses belajar di rumah menggunakan berbagai alternatif media pembelajaran selama proses pembelajaran jarak jauh. Perubahan ini bukanlah suatu hal yang mudah bagi lembaga pendidikan terutama bagi orang tua yang menghadapi perubahan dalam sistem pembelajaran ini. Dalam pelaksanaan pembelajaran jarak jauh, orang tua memiliki peran yang penting bagi proses pembelajaran anak selama di rumah. Namun pada kenyataannya di masa pandemi Covid-19 dan situasi perubahan ini terjadi, orang tua siswa tidak memiliki banyak waktu untuk mendampingi anaknya, karena orang tua yang disibukkan dengan pekerjaan, dan kesibukan lainnya, bahkan tidak sedikit orang tua yang hanya berperan sebagai fasilitator atau hanya sekedar memenuhi ma- 
teri anak saja. Sehingga dalam kegiatan pembelajaran diterapkan pembagian peran dalam proses pembelajaran anak, yaitu antara orang tua dan pendidik. Pada pembelajaran Agama Kristen orang tua siswa mempercayakan pendidikan anak kepada guru pembantu dalam pelaksanaan pembelajaran jarak jauh, sementara secara teoritis orang tua harus berperan (Diana, 2019; Hutapea, 2020).

Berdasarkan uraian di atas peneliti ingin mengetahui sejauh mana peran orang tua dalam proses pembelajaran Pendidikan Agama Kristen selama masa pandemi Covid-19 di SDN 02 Kalirejo Ungaran Timur. Hal ini penting karena dapat mendeskripsikan secara lengkap peran yang telah dilakukan orang tua pada jenjang siswa SD. Berbeda dengan beberapa penelitian terdahulu yang meneliti tentang peran orang tua, penelitian menggunakan pendekatan teoritis seperti peran guru di sekolah. Sementara penelitian Darmawan et al. (2021), Diana (2021), Yulianingsih, Suhanadji, Nugroho, \& Mustakim (2020), Kurniati, Alfaeni, \& Andriani (2020) pendekatan penyajian hasil penelitiannya berdasarkan temuan lapangan. Sementara dalam penelitian ini, peneliti dari awal menetapkan empat peran yang diteliti yaitu peran sebagai guru, peran sebagai motivator, peran sebagai fasilitator, dan peran sebagai pembimbing.

Dari latar belakang di atas rumusan masalah penelitian ini adalah bagaimana peran orang tua pada pembelajaran Pendidikan Agama Kristen di masa pandemi Covid-19 di SDN 02 Kalirejo Ungaran Timur tahun ajaran 2019/2020? Adapun tujuan di dalam penelitian penulisan karya ilmiah ini adalah untuk mengetahui sejauh mana peran orang tua pada pembelajaran Pendidikan Agama Kristen di masa pandemi Covid-19 di SDN 02 Kalirejo Ungaran Timur semester 2 tahun 2019/2020.

\section{Metode}

Penelitian ini menggunakan penelitian kualitatif. Agar penelitian lebih fokus dan tidak meluas dari pembahasan yang dimaksud dan diteliti, maka peneliti membatasi masalah pada: 1) Penelitian ini dilakukan pada siswa yang beragama Kristen di SDN 02 Kalirejo Ungaran Timur, dengan jumlah 3 orang siswa; 2) Penelitian ini untuk melihat bagaimana peran orang tua pada pembelajaran Pendidikan Agama Kristen di masa pandemi Covid-19 di SDN 02 Kalirejo Ungaran Timur, dengan meneliti orang tua siswa yang berjumlah 6 orang dari 3 orang siswa. Untuk mendapatkan data yang diperlukan tentang peran orang tua pada pembelajaran jarak jauh khususnya pada pembelajaran Agama Kristen selama masa pandemi Covid-19 peneliti melakukan proses wawancara kepada 
orang tua siswa. Sementara itu untuk mendapatkan kebenaran dari hasil wawancara kepada orang tua selanjutnya peneliti melakukan wawancara kepada siswa, serta melihat hasil belajar siswa selama proses pembelajaran jarak jauh. Dokumentasi lainnya sehingga mendapatkan hasil apakah orang tua telah melaksanakan perannya selama masa pembelajaran jarak jauh dimasa pandemi Covid-19. Selanjutnya hasil dari data wawancara, dan dokumentasi peneliti gabungkan dengan menarik kesimpulan dan disajikan secara deskriptif naratif.

\section{Hasil dan Pembahasan}

Dari hasil analisis terhadap data-data yang terkumpul diketahui beberapa peran orang tua dalam pembelajaran agama Kristen selama masa pandemi.

\section{Peran Orang Tua Dalam Pembelajaran Jarak Jauh}

\section{Peran Sebagai Guru}

Lingkungan pertama bagi anak adalah keluarganya sendiri, di mana lingkungan keluarga adalah sekolah pertama yang dikenal anak sejak pertama lahir di dunia. Dari lingkungan keluargalah anak bertumbuh, di mana anak mulai diperkenalkan dan mengenal sesuatu yang ada di lingkungannya (Lilawati, 2020). Demikianlah dengan pendidikan yang merupakan lingkungan pertama bagi anak mendapatkan pendidikan. Oleh sebab itu dalam hal ini, orang tua memiliki peran penting yaitu sebagai guru bagi anak-anaknya (Umar, 2015). Anakanak sudah menjadi tanggung jawab dari masing-masing orang tua. Jadi peran dari orang tua yang pertama adalah sebagai guru (Chrismardiyanti, 2020). Hasil wawancara pada Rakhmad (2020) diperoleh informasi bahwa upaya yang dilakukan oleh orang tua selama pembelajaran jarak jauh dalam menjalankan peran sebagai guru adalah dengan membuatkan jadwal belajar di rumah bagi anak. Namun masih ada beberapa orang tua yang tidak membuatkan jadwal bagi anak belajar di rumah, hanya mengikuti jadwal dari sekolah (Gabriela, 2020) yang di mana seharusnya orang tua mengatur jadwal belajar anak sehingga proses pembelajaran di rumah berjalan dengan baik dan anak tetap melaksanakan pembelajaran secara efektif.

\section{Peran Sebagai Motivator}

Keberhasilan pendidikan anak selama proses pembelajaran jarak jauh berlangsung adalah memerlukan motivasi dari orang tua, di mana peran lain da- 
ri orang tua yaitu sebagai motivator bagi anak, memberikan dorongan dengan semangat serta dukungan kepada anak di dalam proses pelaksanaan pembelajaran bagi putra-putrinya sehingga anak memiliki gairah untuk belajar (Lilawati, 2020). Orang tua menyadari bahwa pembelajaran jarak jauh adalah hal yang baru dan bukanlah hal yang mudah bagi siswa di tingkat dasar (SD) (Ari, 2020), sehingga memerlukan dukungan dari orang tua bagi siswa, bahkan memberikan reward kepada siswa sebagai upaya untuk merangsang semangat belajar siswa. Hasil wawancara yang telah dilakukan kepada Hilda (2020) diperoleh informasi bahwa terdapat orang tua yang mulai bosan dalam memberi motivasi atau dukungan kepada anak-anaknya. Hal tersebut diakibatkan karena proses pembelajaran jarak jauh yang cukup panjang dan kesibukan orang tua (Hayati, 2020).

\section{Peran Sebagai Fasilitator}

Peran lain dari orang tua bagi anak adalah sebagai fasilitator, di mana orang tua menyediakan fasilitas, sarana dan prasarana untuk mendukung anak belajar dalam mewujudkan tujuan pembelajaran yang berhasil (Yulianingsih et al., 2020). Hasil wawancara kepada Guntur (2020) mengungkapkan bahwa usaha yang dilakukan oleh orang tua untuk mendukung kelancaran belajar orang tua menyediakan android atau telepon genggam (Gaby, 2020), bahkan orang tua juga menyediakan dana khusus untuk pembelian kuota, juga mendapatkan bantuan kuota khusus belajar untuk mendukung dalam proses pembelajaran jarak jauh siswa belajar di rumah, jadi secara umum tanggung jawab orang tua siswa dalam menyediakan sarana pembelajaran jarak jauh khususnya kuota internet tidak menjadi masalah dalam proses pembelajaran jarak jauh.

Sumber kuota dalam proses pembelajaran jarak jauh siswa berasal dari berbagai sumber, diantaranya berasal dari orang tua siswa, dari wifi lingkungan tempat tinggal, dan dari bantuan pemerintah melalui BOS maupun dari pemerintah langsung. Dapat dikatakan secara umum kuota belajar siswa tidak mengalami hambatan atau kendala dalam proses pembelajaran jarak jauh berlangsung (Efendi, 2020).

\section{Peran Sebagai Pembimbing}

Pembelajaran siswa yang dilaksanakan di rumah akan lebih efektif apabila orang tua membantu untuk mengerjakan tugas tanggung jawab sebagai siswa (Diana, 2019; Subarto, 2017). Adapun tugas dari peran orang tua yaitu, sebagai pembimbing bagi putra dan putrinya, dengan cara mengarahkan dan 
membantu anak dalam proses pembelajarannya seperti mengerjakan tugas dari sekolah, bahkan mengarahkan anak sehingga memiliki pribadi yang lebih baik lagi (Yulianingsih et al., 2020). Memang sudah seharusnya orang tua membimbing anak. Selama masa pandemi Covid-19 semua siswa merasa kesulitan dalam belajar, dan merasa bosan, namun dengan mendapatkan dorongan untuk tetap semangat dari orang tua. Hasil wawancara pada Hilda (2020) diperoleh informasi dirinya tidak mendapatkan perhatian dan dorongan yang penuh dari orang tua. Hal ini terjadi karena adanya kendala dari orang tua untuk melakukan pendampingan. Hal ini terlihat dari hasil belajar siswa masih kurang maksimal. Oleh sebab itu, perlu pembagian waktu dari orang tua untuk mendampingi siswa belajar di rumah, sehingga siswa dapat mempertahankan dan meningkatkan hasil belajarnya.

\section{Faktor Kendala Peran Orang Tua}

Dalam menjalankan peran dalam pembelajaran jarak jauh di masa pandemi Covid-19, terhadap beberapa kendala yang disebabkan oleh beberapa faktor, diantaranya:

Tabel 1. Faktor Kendala Peran Orang Tua

\begin{tabular}{ll}
\hline \multicolumn{1}{c}{ Faktor Kendala } & \multicolumn{1}{c}{ Deskripsi } \\
\hline Pemahaman & Pemahaman yang belum utuh tentang peran orang tua \\
& dalam proses pembelajaran jarak jauh. Secara umum \\
& orang tua masih belum memahami tentang pelaksanaan \\
& pembelajaran jarak jauh, baik pada prosesnya, materi, \\
& maupuan media pembelajarannya. \\
\hline Sosialiasi Tentang & Sosialisasi yang minim tentang peran orang tua dalam \\
Peran Orang Tua & pembelajaran jarak jauh baik dari sekolah ataupun \\
& pendidik. Orang tua masih kurang memperoleh \\
& sosialisasi terkait batasan peran orang tua dalam \\
& pendampingan anak belajar dari rumah. \\
\hline Pola Baru & Orang tua yang diwawancarai mengungkapkan bahwa, \\
Pendidikan & pembelajaran jarak jauh merupakan hal yang baru. Hal \\
& ini menyebabkan orang tua mengalami kesulitan dalam \\
& memberikan pendampingan pada anak belajar dari \\
& rumah. Misalnya: orang tua kurang memahami tentang \\
& penggunaan beberapa flatform pembelajaran jarak jauh. \\
\hline
\end{tabular}


Kesibukan Orang Kondisi orang tua yang tetap bekerja di masa pandemi Tua menyebabkan minimnya alokasi waktu mendampingi anak. Hal ini menyebabkan jumlah pertemuan antara anak dan orang tua untuk pendampingan belajar menjadi sangat terbatas. Itu sebabnya pendampingan orang tua menjadi sangat minim.

Kurangnya peran orang tua memberi dampak pula bagi proses pembelajaran siswa. Hal tersebut terbukti dari hasil belajar siswa yang tidak signifikan jika dibandingkan sebelum pandemi.

Faktor pemahaman orang tua yang ditemukan di atas serupa dengan temuan Mufaziah dan Fauziah (2020) bahwa kecakapan orang tua menjadi faktor kendala pendampingan. Pemahaman orang tua terkait pembelajaran daring dan materi pembelajaran dapat menimbulkan kesulitan dalam pendampingan terhadap anak. Sementara pemahaman terhadap penggunaan media pembelajaran jarak jauh dapat menimbulkan kebingungan pada orang tua.

Temuan di atas berbeda dengan temuan penelitian Cahyati dan Kusumah (2020). Temuan Cahyati dan Kusumah lebih pada kendala pada kuota, sementara dalam penelitian ini kendala adalah faktor pemahaman orang tua, sosialiasi tentang peran orang tua, pola baru pendidikan, dan kesibukan orang tua. Kondisi orang tua yang bekerja menimbulkan kesulitan besar bagi orang tua untuk memberikan pendampingan pada anak (Komariah, Sakbaniah, Juliani, Pratama, \& Armada, 2021; Wardani \& Ayriza, 2020). Orang tua menjadi terkendala membagi waktu di tengah beratnya tugas bekerja dengan kenormalan baru.

\section{Implikasi}

Secara teoritis, hasil penelitian ini menunjukkan bahwa keempat ranah peran pendidik dapat dilaksanakan pula oleh orang tua. Hanya porsi berbeda dengan guru di sekolah. Sebagaimana guru di sekolah, orang tua juga dapat menjalankan peran yang sama sebagai guru, motivator, fasilitator, dan pembimbing. Dengan demikian, pasca pandemi peran yang sama dapat dioptimalkan sehingga upaya mewujudkan pendidikan yang bermutu dapat terwujud.

Secara praktis, hasil penelitian menunjukkan bahwa dimungkinkan dilakukan kerja sama dengan pembagian tugas yang jelas antara guru dan orang tua. Hal ini didasarkan bahwa orang tua dapat menjalankan peran yang sama seperti guru, meski dalam porsi yang berbeda. 


\section{Rekomendasi Penelitian Lanjutan}

Dari penelitian ini, tampak ada peran orang tua dan kendalanya dalam pembelajaran jarak jauh siswa. Dari proses penelitian, peneliti memandang perlu dilakukan penelitian lanjutan untuk mengetahui sejauh mana efektivitas peran orang tua. Sementara pada sisi lain, penelitian lanjutan perlu juga meneliti tentang respon siswa sekolah dasar terhadap orang tua ketika menjalankan peran sebagai guru. Mengingat tidak semua orang tua memiliki kemampuan dan tingkat pendidikan yang sama maka dapat diteliti pula dengan pendekatan kuantitatif terkait pengaruh latar belakang pendidikan orang tua terhadap implementasi peran orang tua dalam pembelajaran jarak jauh.

\section{Kesimpulan}

Kebijakan pemerintah terkait dengan pembelajaran jarak jauh selama pandemi Covid-19 sangat berdampak terhadap peran orang tua siswa dalam proses pembelajaran Pendidikan Agama Kristen di SDN 02 Kalirejo Ungaran Timur Tahun Ajaran 2019/2020. Orang tua tidak hanya menjalankan peran dalam proses pembelajaran namun juga memastikan putra-putrinya terhindar dari paparan virus Covid-19.

Adapun peran orang tua yang diharapkan selama pembelajaran jarak jauh di masa pandemi Covid-19 adalah sebagai berikut: 1) Orang tua berperan sebagai guru bagi anak, di mana orang tua memiliki tugas bukan hanya mengajar atau bukan hanya menjadi teladan bagi anak namun bertugas juga dalam mendisiplin anak belajar dengan cara membuat jadwal atau menetapkan waktu belajar anak di rumah, selain dari jadwal yang ada di sekolah; 2) Tidak hanya sebagai guru saja namun orang tua juga berperan sebagai motivator, bertugas untuk memberi dorongan dan semangat kepada anak sehingga anak memiliki gairah untuk belajar; 3) Sebagai fasilitator, orang tua menyediakan fasilitas untuk anak, dalam mendukung proses belajar; 4) Sebagai pembimbing dengan mengarahkan anak untuk melakukan apa yang baik untuk dilakukan, dan membimbing anak mengajarkan anak untuk berdoa.

Selain itu, belum semua orang tua siswa menjalankan perannya dalam proses pembelajaran jarak jauh di masa pandemi Covid-19. Hal tersebut disebabkan beberapa faktor, diantaranya: 1) Pemahaman yang belum utuh tentang peran orang tua dalam proses pembelajaran jarak jauh; 2) Belum optimalnya sosialisasi tentang peran orang tua dalam pembelajaran jarak jauh baik dari sekolah ataupun pendidik; 3) Pembelajaran jarak jauh merupakan hal yang baru 
bagi orang tua siswa; dan 4) Orang tua yang bekerja membuat alokasi waktu pendampingan menjadi terbatas.

\section{Daftar Rujukan}

Ari. (2020). Wawancara tentang peran orang tua sebagai Motivator di masa pandemi. Cahyati, N., \& Kusumah, R. (2020). Peran Orang Tua Dalam Menerapkan Pembelajaran Di Rumah Saat Pandemi Covid 19. Jurnal Golden Age, 04(1), 152-159. Retrieved from http:/ / www.ejournal.hamzanwadi.ac.id/index.php/jga/article/view/2203

Chrismardiyanti. (2020). Wawancara peran orang tua sebagai guru selama masa pandemi Covid-19.

Darmawan, I. P. A., Nalle, P. A., Magdalena, M., Marderina, M., \& Julita, Y. (2021). Upaya Sekolah dan Keterlibatan Orang Tua dalam Pembelajaran di Masa Pandemi Covid-19. Jurnal Komunikasi Pendidikan, 5(2), 175-185. https:// doi.org/10.32585/JKP.V5I2.1254

Diana, R. (2019). Prinsip Teologi Kristen Pendidikan Orang tua terhadap Anak di Era Revolusi Industri 4.0. BIA': Jurnal Teologi Dan Pendidikan Kristen Kontekstual, 2(1), 27-39. https://doi.org/10.34307/b.v2i1.79

Diana, R., Darmawan, I. P. A., \& Br Simamora, E. S. (2021). Kerjasama Orang Tua Dan Guru Dalam Pembelajaran Paud Di Masa Pandemi Covid-19. VOX DEI: Jurnal Teologi Dan Pastoral, 2(1), 1-16. https:/ / doi.org/10.46408/vxd.v2i1.42

Efendi, N. (2020). Implementasi Karakter Peduli Lingkungan di Sekolah Dasar Lolong Belanti Padang. Jurnal Komunikasi Pendidikan, 4(2), 62. https:// doi.org/10.32585/jkp.v4i2.460

Ekayanti, N. W., \& Puspawati, D. A. (2020). Peran Orang Tua Dalam Mendidik Anak Ditengah Pandemi Covid-19. Prosiding Webinar Nasional Universitas Mahasaraswati 2020. Denpasar: Universitas Mahasaraswati Press. Retrieved from https:/ / e-

journal.unmas.ac.id/index.php/prosidingwebinarwanita/article/view/12 46

Gabriela. (2020). Wawancara tentang Peran orang tua sebagai guru di masa pandemi. Gaby. (2020). Wawancara tentang tugas orang tua sebagai fasilitator.

Guntur. (2020). Wawancara tentang peran orang tua sebagai fasilitator di masa pandemi.

Handayani, L. (2020). Keuntungan, Kendala dan Solusi Pembelajaran Online 
Selama Pandemi Covid-19: Studi Ekploratif di SMPN 3 Bae Kudus. Journal Industrial Engineering \& Management Research (JIEMAR), 1(2), 2722-8878. https:// doi.org/10.7777/jiemar.v1i2

Hayati, A. S. (2020). Peran Orang Tua dalam Meningkatkan Motivasi Belajar Anak Dengan Sistem Daring pada Masa Pandemi di Desa Depokrejo, Kebumen. Tasyri': Jurnal Tarbiyah-Syari'ah Islamiyah, 27(2), 23-32. Retrieved from

http:/ / ejournal.kopertais4.or.id/pantura/index.php/tasyri/article/view/ 3552

Hilda. (2020). Wawancara tentang orang tua sebagai motivator.

Hutapea, R. H. (2020). Kreativitas Mengajar Guru Pendidikan Agama Kristen Di Masa Covid-19. Didache: Journal of Christian Education, 1(1), 1. https:// doi.org/10.46445/djce.v1i1.287

Komariah, K., Sakbaniah, S., Juliani, S., Pratama, M. E., \& Armada, B. (2021).

Kendala Orang Tua Dalam Mendampingi Anak Belajar Dari Rumah Pada Masa Pandami Covid 19 Di Desa Perlang Kabupaten Bangka Tengah. IJoCE: Indonesian Journal of Counseling and Education, 2(2), 37-43. Retrieved from https://jurnal.lp2msasbabel.ac.id/index.php/IJoCE/article/view/1975 Kurniati, E., Alfaeni, D. K. N., \& Andriani, F. (2020). Analisis Peran Orang Tua dalam Mendampingi Anak di Masa Pandemi Covid-19. Jurnal Obsesi : Jurnal Pendidikan Anak Usia Dini, 5(1), 241. https:// doi.org/10.31004/obsesi.v5i1.541

Lilawati, A. (2020). Peran Orang Tua dalam Mendukung Kegiatan Pembelajaran di Rumah pada Masa Pandemi. Jurnal Obsesi : Jurnal Pendidikan Anak Usia Dini, 5(1), 549.

https:// doi.org/10.31004/obsesi.v5i1.630

Mufaziah, E., \& Fauziah, P. (2020). Kendala Orang Tua dalam Mendidik Anak Usia Dini pada Saat Pandemi Covid 19. Jurnal Obsesi : Jurnal Pendidikan Anak Usia Dini, 5(2), 1045-1051. https:/ / doi.org/10.31004/OBSESI.V5I2.746

Nainupu, A. M. Y., \& Emiyati, A. (2020). Kunci Keberhasilan Seorang Anak Dalam Pemaparan Alkitab. Didache: Journal of Christian Education, 1(2), 91. https:// doi.org/10.46445/djce.v1i2.329

Pramana, C., Susanti, R., Ernawati, K., Darmawan, I. P. A., Miftah, M. Z., Lestyowati, J., ... Ramadhani, R. (2021). Distance Learning In Primary 
Schools During The Covid-19 Pandemic In Indonesia: Challenges, Solutions, And Projections. Turkish Journal of Computer and Mathematics Education (TURCOMAT), 12(4), 263-270.

https://doi.org/10.17762/turcomat.v12i4.502

Purwanto, A., Pramono, R., Asbari, M., Hyun, C. C., Budi Santoso, P., Wijayanti, L. M., ... Santoso, P. B. (2020). Studi Eksploratif Dampak

Pandemi COVID-19 Terhadap Proses Pembelajaran Online di Sekolah

Dasar. EduPsyCouns: Journal of Education, Psychology and Counseling, 2(1), 112. Retrieved from https://ummaspul.e-

journal.id/Edupsycouns/article/view/397

Rakhmad. (2020). Wawancara tentang Keterlibatan Orang Tua dalam Pembelajaran di Masa Pandemi.

Ritonga, Z. S. (2020). Analisis Implementasi Manajemen Berbasis Sekolah di Kecamatan Pantai. Jurnal Komunikasi Pendidikan, 4(1), 28.

https:// doi.org/10.32585/jkp.v4i1.432

Subarto, S. (2017). Momentum Keluarga Mengembangkan Kemampuan Belajar

Peserta Didik Di Tengah Wabah Pandemi Covid-19. Adalah: Buletin Hukum

Dan Keadilan, 4(1). https://doi.org/10.15408/adalah.v4i1.15383

Umar, M. (2015). Peranan Orang Tua Dalam Peningkatan Prestasi Belajar Anak.

JURNAL EDUKASI: Jurnal Bimbingan Konseling, 1(1), 20.

https:// doi.org/10.22373/je.v1i1.315

Undang-Undang Republik Indonesia Nomor 20 Tahun 2003 Tentang Sistem

Pendidikan Nasional. (n.d.).

Wardani, A., \& Ayriza, Y. (2020). Analisis Kendala Orang Tua dalam

Mendampingi Anak Belajar di Rumah Pada Masa Pandemi Covid-19.

Jurnal Obsesi : Jurnal Pendidikan Anak Usia Dini, 5(1), 772.

https://doi.org/10.31004/obsesi.v5i1.705

Yulianingsih, W., Suhanadji, S., Nugroho, R., \& Mustakim, M. (2020).

Keterlibatan Orangtua dalam Pendampingan Belajar Anak selama Masa

Pandemi Covid-19. Jurnal Obsesi : Jurnal Pendidikan Anak Usia Dini, 5(2),

1138-1150. https://doi.org/10.31004/obsesi.v5i2.740 